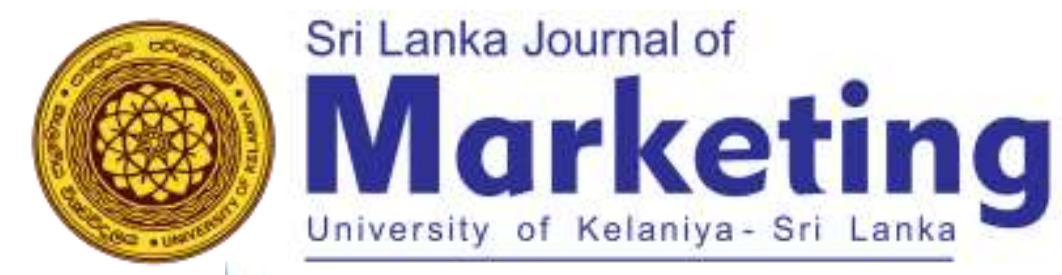

\title{
Impact of Celebrity Brand Endorsement on Consumer Buying Behaviour on Modern Trade in Sri Lanka
}

\author{
P. V. M. V. D. Udovita \\ Assistant Lecturer, University of Kelaniya, Sri Lanka \\ 2017_viduni@kln.ac.lk
}

\section{ABSTRACT}

This paper has been developed as a conceptual paper by rationalizing the existing literature sources to build arguments on two main concepts namely Celebrity Endorsement and consumer brand behaviour on Sri Lankan modern trade industry. This study is specially focused on Sri Lankan modern trade sector which has remarked a significant position in the local economy. It shows a higher degree of contribution in the practical scenario of celebrity endorsements in the Sri Lankan modern trade industry, but empirical knowledge is lack to investigate how celebrity endorsements works in modern trade industry branding perspectives. The study based on empirical studies basing the Tears model by Shimp (2003) indicated that trustworthiness, expertise, attractiveness, respect of the celebrity are key factors that impact on celebrity endorsement. Finally, it concludes the paper with some research directions and priorities for the future studies.

Keywords: Celebrity Endorsement, Consumer Buying Behavior, Modern Trade, Sri Lanka 


\section{Background of the Study:}

Celebrities are identified as one of the prominent communication models who can make a significant influence on the consumer purchase intention (Dissanayake \& Ismail, 2015). Thus, celebrity endorsement is considered as one of the most known marketing tools irrespective of the product categories and across all the industries. Most of the renowned brands all around the world are considering celebrity endorsement as a winning strategy to build a unique identity for the brand. Moreover, creation and enhancement of a brand loyalty and increasing the number of customers are the crucial expected effect of the celebrity endorsement (Udovita \& Hilal, 2018). Additionally, celebrity endorsement also form new market segments in which customers are without attitude and preferences to the brand previously (Byrne et al., 2003).

\section{i. Sri Lankan Celebrity Endorsement for Supermarkets:}

As per multiple studies carried out in Sri Lankan context by various authors, celebrities are identified as one of the prominent communication model used in advertising and promotions in Sri Lanka to make a significant influence on the consumer purchase intention (Dissanayake, 2018; Dissanayake \& Ismail, 2015; Hennayake, 2017; Koththagoda \& Weerasiri, 2017; Kumara, 2016; Perera, Dissanayake, \& Wanninayake, 2018; Udovita \& Hilal, 2018; Wanninayake \& Randiwela, 2007). In order to achieve a successful endorsement, along with the popularity of the celebrity, the complementary qualities, talents, competencies, respect, features and the capabilities of the celebrity has to be matched with the brand features and it has been widely advertised and communicated through mass media, social media as well as through digital media (Madhuhansi, 2017). The usage of celebrity endorsements is significant in local business context of Sri Lanka particularly referring to FMCG, Supermarket chains and consumer durables. However, when looking at industry related cases, it is evident that Sri Lankan super market industry have been using celebrities quite competitively lately. For example Arpico Super by Dominique Keller, Laugfs Super by Blok \& Dino, Cargills Food City by Sanath Jayasuriya and Keells Super by Kumara Sangakkara.

\section{ii. Overview of the Supermarket Industry in Sri Lanka:}

The modern trade concept was initiated in Sri Lanka during the colonial period of 1980's yet the significant boom and an expansion in the industry started from 2000 onwards (Wanninayake \& Randiwela, 2007). Today, the supermarket industry is at the growing stage of its industry life cycle due to the westernized modern lifestyles of Sri Lankans. Compared to the past, the convenience has become the major factor sought but the Sri Lankan consumers buying behaviors and customers prefer more convenience and quality over price. The modern trade is in a great position to fulfil this requirement as well. 
Over the past decade the retail landscape in Sri Lanka has changed with the evolving needs of shoppers. The ubiquitous traditional trade of yesteryear family-owned grocery chains, small independent stores, and informal merchants is slowly giving way to modern trade; supermarkets and hypermarkets which seems to cater to a rapidly urbanizing population looking for competitive prices and greater convenience (Mawilmada, 2017). While still in the low double digits in terms of overall penetration, modern trade seems poised to take over Sri Lanka's retail space. This was further validated by a Fitch Ratings report from November of 2017 which stated strong growth prospects in the mid-teens (Fitch Ratings Ltd, 2017). Further data from consumer Research Company, Nielsen shows that 12\%-15\% of FMCG sales in Sri Lanka in 2016 were generated by modern grocery retail, which is much lower compared with regional peers with similar characteristics.

There are around 600 supermarket outlets in Sri Lanka which is dominated by the major supermarket chains of Cargills Food City, Keells Super, Arpico Super and Laugfs as private sector entities while Lanka Sathosa as a state-owned entity (Fitch Ratings Ltd, 2017).

\section{iii. Purpose of the Study:}

Many research evidences proved that celebrity brand endorsements helps organizations to stimulate the consumer's buying behavior and influences their attitudes towards the brand. Belch, Belch and Belch (2001), argued that organizations should use the best possible celebrity who can represent the brand image with a good reputation among the people (Belch, Belch, \& Belch, 2001). Moreover, as cited by Mukherjee (2009), Lalwani (2006), argued, in order to popularize a brand among customers through celebrity endorsement and influence consumers, these target group of customers must aware about particular celebrity, celebrity must link with the endorsed product/ brand, celebrity must have esteem among customers and celebrity must project characteristics of the product among customers (Mukherjee, 2009)

The organizations should be very cautious in selecting and matching the most appropriate celebrity endorser in representing their respective brand (Madhuhansi, 2017). However, the significant matter is to what extend it has assessed the effectiveness of those celebrity endorsement strategies towards brand related consumer behaviors. Further, Wanninayake \& Dissanayake (2009), revealed that the influence of consumer behavior in relation to celebrity advertising in Sri Lanka is not at significant level as it is expected by the intensity of advertising efforts made. Further the author has specifically identified an empirical gap on the literature regarding the impact on celebrity endorsement on the consumer behavior shown by the consumers on modern trade. Accordingly, the purpose of the current study is to identify the extent to which the Celebrity Endorsement makes an impact on modern trade consumer behavior in Sri Lanka. 


\section{iv. Methodology:}

In this research the author follows a deductive approach where the explanations and arguments are supported by empirical evidences and associated theories. The researcher has reviewed journal articles, industry publications and reports from institutes such as research centers, technology advisory and strategy consultancies as well as report from credible web sites to understand "the extent to which the Celebrity Endorsement makes an impact on modern trade consumer behavior in Sri Lanka". Accordingly, literature review was employed as the main research tool. The paper is organized as a concept paper whilst arguments were empirically supported. Finally, the author discusses and conclude the paper postulating future research directions in line with the synthesized discussions.

\section{Theoretical Background:}

\section{i. Celebrity Brand Endorsement:}

Celebrity endorsement has become one of the protruding areas in empirical studies as well as in practical managerial implications owing to its influence on brand equity, brand loyalty, consumer behavior, consumer psychology as well as its commercial viability towards a brand. The celebrity endorsement comes through the character called celebrity (Perera, Dissanayake, \& Wanninayake, 2018). Grant defines a celebrity endorser as "any individual who enjoys public recognition and who uses this recognition on behalf of a consumer good by appearing with it in an advertisement" (Mccracken, 1989). Various authors have identified the term "Celebrity" in many perspectives. As cited by Dissanayake (2018), a celebrity can be a well-known personality (Shimp, 2010), a name made by news (Choudhury \& Iyer, 2008), notion of a reference group (Shiffman \& Kanuk, 2006), credible spokespersons (Hung, 2014), a personality recognized by society (Choi \& Berger, 2010) and a psychological bridge that connects consumers to respond endorsed-brands (Kumara, 2016).

On the other hand, celebrity endorsement is considered as one of the most known marketing tools in the FMCG industry which is a highly utilized tool among most of the renowned brands all around the world and considered as a winning strategy to build a unique identity for the brand (Udovita \& Hilal, 2018). In today's complex business environment consumers always tend to remember the ideas and products with glamorized ideas which have a significant reason to remember. As such, business organizations are highly looking for communicating their brands with the customers using celebrity endorsements. This is because consumers in today's' glamorous world are willing to consume products, services and ideas which their favorite celebrities recommend. Thus companies spend millions of dollars annually on celebrity endorsement contracts solely due to its persuasive role in communication (Tripp, Jensen, \& Carlson, 1994). 
There are different models and theories found in early studies which discuss the characteristics of celebrities to be possessed in making an endorsement effective.

\section{ii. Models of Celebrity Endorsement:}

It is crucially important for the marketers to make the most correct decision when making the choice of the celebrities for their brand endorsement (Temperley \& Tangen, 2006). Some scholar have made efforts to develop some models regarding this in order to assist marketers in choosing celebrity endorses i.e. Source Credibility Model which has developed by Hovland, Janis, \& Kelley (1954), the Source Attractiveness Model introduced by McGuire (1985), Meaning Transfer Model by McCracken (1989) and the Product Matchup Hypotheses by Kamins (1990), also contributes further in this regard.

The source Attractiveness Model is much more considering the attributes such as likability, familiarity and similarity (McGuire, 1985). This means that the marketers are more focus on selecting celebrities based on their physical attractiveness including celebrities' physical appeal and their social status. It is obvious that the attractive celebrities have the ability to influence the consumers' attitudes but as per Byrne, Whitehead, \& Breen (2003), there is no much evidences regarding whether the attractive celebrities can influence the repeat purchase behavior of the consumers. According to Bush, Martin, \& Bush (2004), most of the people think that the good-looking people are more persuasive, therefore, attractiveness of the celebrity is a major factor of getting customer attraction towards the brand.

As per the source credibility model by Hovland et al (1953), the credibility of the endorsers plays a very significant and crucial role in convincing and attracting the target customer group. According to Soloman (2002) persuasion of the consumers is the central focus of any advertising effort which involves making active effort to change the consumers' perception and attitudes regarding the brand advertised. The Source Credibility Model explains that the success of the advertising message is highly depends on the trustworthiness and the expertness of the source used (Hovland et al, 1953). It is assume that if a source is credible, there is a greater possibility to accept the influence by the target customers and use it. According to the research evidences of the Daneshvary and Schwer (2000) the buying behavior and purchase intention of the consumers can be positively influenced by using credible sources to endorse their brand. According to Till and Shimp (1998) if marketers want to send a credible image with their advertisements, they should choose a celebrity with trustworthiness, objectiveness, persuasiveness and expertise.

On the other hand McCracken (1989) developed Meaning Transfer Model to explain the advantages of celebrity endorsement including cognitive and affective aspects. This is based on the idea that in the consumer society, which is organized around culture, celebrities have a shared cultural significance in the eyes of consumers (McCracken, 1989). McCracken defines this transfer as the translation of the meaning of celebrity to a product or brand, e.g. in advertisements with celebrity spokespersons. 
Endorsement is effective when an individual who buys and consumes the product appropriates the meaning associated with the celebrity, which has been transferred to the product. This is referred to as the making congruence between personality and brand that facilitates meaning and affect transfer from one to the other (Misra and Beatty, 1990; Kamins and Gupta, 1994, Lynch and Schuler, 1994).

Congruence is also referred by several other names such as fit, link, match up effect and etc. and it is defined as the "fact that the highly relevant characteristics of the spokesperson are consistent with the highly relevant attributes of the brand" (Misra \& Beatty, 1990). There are two dimensions of congruence namely expectancy and relevance where the relevance reflects the extent to which the information contained in the stimulus contributes to or prevents a clear identification of the main theme or message being communicated. Expectancy refers to the degree to which an item or piece of information fits into a predetermined pattern or structure evoked by this theme (Anzmac, 2009). As per the literature findings, researchers such as Erdogan and Baker (2000); Till and Busler (2000); Batra and Homer (2004) found stronger association between relevance or congruence of the celebrity towards the brand and the consumer attitudes and purchase intention.

According to the argument made by Seno \& Lukas (2007), it stated that there are five factors affecting the effectiveness of celebrity endorsement. Those factors can be divided into two categories as the source based factor which are related and are controllable by the celebrity, i.e. credibility and attractiveness and management-based factor that are related to how marketing department manages celebrity and could be controlled through management i.e. celebrity product congruency, celebrity multiplicity, and celebrity activations as management based factors (Hennayake, 2017).

According to the reference made by Shimp (2003) introducing "TEARS" model states there are two main components that motivates the endorsers effectiveness i.e. celebrity attractiveness and credibility. Accordingly it signifies five attributes namely trustworthiness and expertise belongs to the credibility component, while physical attractiveness, respect, and similarity are dimensions of attractiveness as the key attributes that motivates the endorsers effectiveness (Koththagoda \& Weerasiri, 2017).

\section{iii. Consumer Buying Behavior:}

According to Jain (2010) consumer buying behavior is all about making the purchase decision to consumer the goods and services of the company by the consumers. Kotler and Armstrong (2001) define consumer buying behavior as the individuals or households' behavior to buy products and services for the personal consumption. After considering these consumption decisions, as explain by Weatherill et al (2002) consumers will only make the purchase decision about a products and service which can give them the best satisfaction for their needs and wants. The same idea also presented by Solomon and Rabolt (2004) with more description. They define consumer buying behavior as the study of the 
consumers including individual or groups decision to select, purchase, use and dispose a good, service, experience or idea in order to fulfil their expectations to satisfy the needs and wants. This definition also confirmed that consumer buying behavior is mainly involved with satisfying one's needs and expectations. But the modern consumer buying behavior concept clarifies that consumers will not consider only the satisfaction of their needs and wants (which is the functional purpose of products) but also what the products actually mean for them and then consumers will establish a long term relationship with that product. According to Solomon and Rabolt (2004) the nature of the product relationship which consumers want to establish are varying with interdependent, love, nostalgic attachment and selfconcept attachment. Therefore, it is clear that consumers just not make the product decision based on satisfaction of needs but also their buying behavior and purchase decision is based on the relationship which they can establish with the products.

\section{iv. Impact of Celebrity Brand Endorsement on Consumer Buying Behavior:}

Marketers are using various styles of advertising in order to send the brand and product message to the customers with the aim of influencing consumer brand choice behavior and it has been identified the celebrity brand endorsement as the very popular choice among these various advertising styles and forms (Alsmadi, 2006). This is because, according to Kurzman et al (2007) celebrities has the omnipresent feature among the individuals in the society which blazing the lasting impression. The influence which make by celebrities on consumers is very large (Alperstein, 1991). This is mainly because, as McCutcheon et al (2003) explain the individuals are very much like to imitate and admire their favourite celebrities. This becomes the celebrity brand endorsement quite sought among all other advertising techniques. Therefore, celebrities can be considered as the most influential reference groups which have the ability to stimulate consumers' behavior.

According to Daneshvay and Schwer (2002) consumers who are strongly attached with the celebrity brand endorsement has a greater influence over their buying behavior and purchase decision of products and brand. Gen (2006) also confirmed that consumers are willing to purchase the products and consume the brands which are endorsed by their favourite famous celebrities. Therefore, the celebrity brand endorsement can be understood as a marketing principle which can use by the organizations to stimulate the consumer buying behavior (Christina and Schlecht, 2003). According to the research conducted by Khartri (2006) found that celebrity brand endorsement is a key marketing promotional activity which can be used to strengthen the company's brand and it act as a stimulation which influence the consumer buying behavior.

According to Spry et al (2011) celebrity brand endorsement positively and significantly affects the advertising effectiveness, brand recognition, brand recall and it has the ability to impact on the follow though and the purchase intention of the consumers. This evidence proves that celebrity brand endorsement has a positive impact on the consumer buying behavior. There are some recent studied 
regarding celebrity brand endorsements. For example Hakimi et al (2011) undertook a study regarding celebrity endorsement and how it impacts on young adults, Hung et al (2011) studied the relationship between celebrity worship and the purchase intention and Spry et al (2011) studied how celebrities are credible on creating the consumer-based equity of the brands. According to Yoo and Donthu (2001) customer based brand equity includes meaningful memories about the brand, perceived quality of the brand, brand awareness and brand loyalty. Spry et al (2001) found that celebrity endorsements help organizations to influence the consumer based brand equity combining all these aspects.

Nevertheless, as per Chan (2010) today's advertisements are largely targeting adolescents to celebrity appeals. It is very important to consider the adolescent consumers by the marketers because those customer groups have the most potential purchasing power than others (Bush et al, 2004). Especially when marketers endorse their brand using celebrity, it is very significant to target adolescent because adolescent largely perceive the celebrities as their ideal self-image which they use to develop their own physical appearance, values, attitudes and personality traits similar to the celebrities (Boon \& Lomore, 2006). Martin and Bush (2004) found that there is a positive impact on celebrity brand endorsement and the consumption behavior and purchase intention of American adolescents. Buksa and Mitsis (2011) also found that sport celebrities have a greater impact on the generation Y consumers purchase intention and word-of-mouth recommendations of the brand in Australia. A similar positive and significant relationship between celebrity endorsement and purchase intention has been found among the teenagers in South Africa (Makgosa, 2010).

Even though there are considerable potential benefits from the celebrity brand endorsement as discussed, the cost and the risk also associated with celebrity endorsement of brands. The main risk behind the celebrity brand endorsement is the fact that even through companies are largely investing on celebrities; they cannot control the future behavior and the reactions of those celebrities (Till \& Shimp, 2013). It is inevitable if those celebrities generated some negative publicity due to their behavior, there is a potential risk of having a negative publicity towards the brand they endorse. According to the findings of Agrawal and Kamakura (1995)'s research, there is a decreasing returns accompanied with the celebrity brand endorsement due to the negative publicity generated by the celebrities, but meantime the cost associated with the celebrity on-board with the brand is very high. As such it is very crucial for the marketers to choose only the celebrities who have a positive image among the public and who are best fit with the brand they are going to endorse (Belch and Belch, 2001). When celebrities create a negative publicity which impact on brand negatively, organizations are using pull back strategies and cancel the contract with those celebrities which are a huge cost for the company.

Kulkarni and Gaulkar (2005) also explained another major drawback of celebrity endorsement which is the 'Vampire Effect' which is referred to as the overshadowing of the celebrity than the brand. This is possible because consumers who are strongly attached with celebrity might forget the brand they 
advertised instead of they are more concentrates on the celebrities who are endorsing the brand. But it is very significant to understand by the marketers, that the brand should be the star but not the celebrity (Cooper, 1984). There is another drawback with celebrity endorsements where celebrities become the endorsers of more than one product or brand, because there is a possibility to celebrity overexposure and the greed (Erdogan, 1999). According to the research evidences of Redenbach (2000) the credibility and the likeability of the celebrity and the attitude towards the advertisement might take very carelessly by the target customers if the celebrity show up in more than one product or brand.

\section{Conceptual Framework and Hypothesis Development:}

In formulating the conceptual framework for this research and development of hypotheses, researcher has adopted previous studies. Although there many studies carried out in the determining factors of celebrity endorsement, Ibok (2013) and Shahrkh \& Arefi (2013) adopted trustworthiness, attractiveness and credibility as independent variables. Audi et al., (2015) has incorporated congruency, activation and multiplicity of endorsers in addition to the stated variables in the previous studies. Further Khan et al., (2016) has also used trustworthiness and congruency for the celebrity endorsement and its influence on purchase intention. For this Sri Lankan supermarket industry based study, researcher has developed the model by using the constructs of Shimp's TEARS model (2003) and consumer purchase intention as dependent variable.

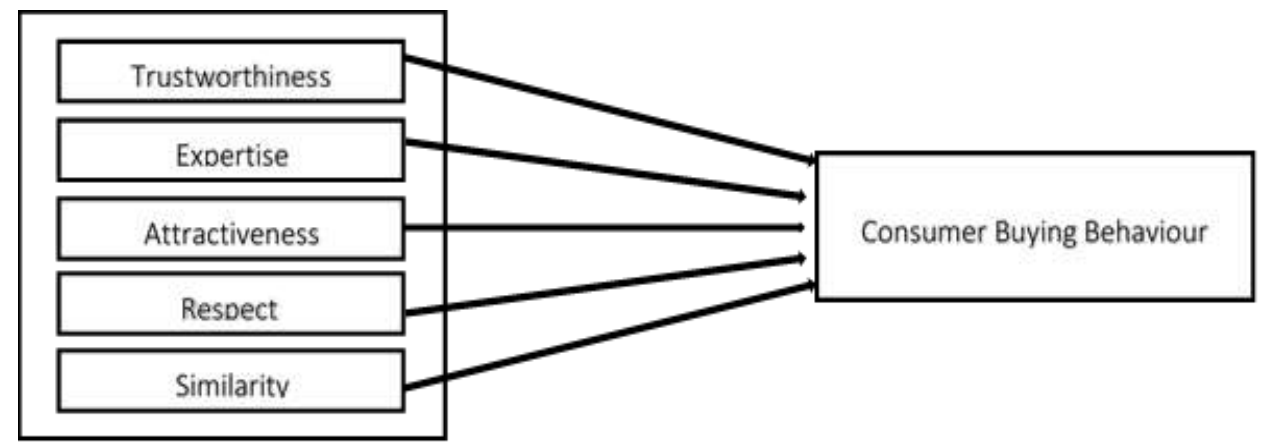

Figure 1: Conceptual Framework (Shimp, 2003)

The proposed model arrests that consumer purchase intention is impacted the celebrity's trustworthiness, expertise, attractiveness, respect and similarity. According to this model, following hypotheses were derived;

- H1: There is a significant relationship between trustworthiness of the celebrity endorser and consumer buying behaviour on modern trade.

- H2: There is a significant relationship between expertise of the celebrity endorser and consumer buying behaviour on modern trade.

- H3: There is a significant relationship between attractiveness of the celebrity endorser and consumer buying behaviour on modern trade. 
- H4: There is a significant relationship between respect of the celebrity endorser and consumer buying behaviour on modern trade.

- H5: There is a significant relationship between similarity of the celebrity endorser and consumer buying behaviour on modern trade.

\section{Conclusion and Future Research Direction:}

This research study is mainly carried out to understand whether the celebrity brand endorsement has an impact on the consumer buying behavior of Modern trade in Sri Lanka. Thus, in this study, celebrity characteristics are measured by using five discrete attributes described in "TEARS model" as Trustworthiness, Expertise, Attractiveness, Respect and Similarity which is explained by Shimp (2003). According to Priyankara, Weerasiri, Dissanayake, Jinadasa (2017) found that consumers usually require endorsers to be physically attractive if they are to increase the recognition of and purchase intentions towards a product or service. As per a study done by Hennayake (2017) revealed that consumers report higher self-brand connections for brands that are consistent with the image of a celebrity that they aspire to be like, particularly in the case when the image of the celebrity and the brand match.

Specifically when focusing to the Sri Lankan context in this regard, marketers need to be smart enough to choose celebrities in their product or service advertisement, especially for Modern trade supermarket advertising, the personality of celebrity has to link with the product and service what he/she is advertising on media. The right choice of celebrity for the right product advertisement is highly profitable for the company. We can confidently recommend companies that they should endorse celebrities in their advertisement because people really follow those celebrities and whatever they market in ads they wish and show inclination to buy it.

It is noted that in Sri Lankan context there are lack of research evidences and literature regarding how celebrity endorsement influence consumers towards modern trade which resulted in a research gap. Therefore, the findings and the discussion of the present study minimize the research gap by contributing to the existing knowledge especially regarding the different attributes of celebrities that influence consumer buying behavior. On the other hand, findings of the study also significant practically as the findings can be used by the company to understand how successful is assigning the celebrities such as Kumara Sangakkara, Sanath Jayasuriya, Blok and Dino etc. as their brand endorsers by the current modern trade channels and how influential their presence towards changing consumer behavioral intentions.

In addition to the said perspective, particularly, the author suggests that it is prudent if the celebrity endorsement can be compared with non-celebrity endorsement in the same industry in order to analyses what method is most effective towards attracting customers and stimulating their behavioral intention. 
And also, unlike to a product or a service, when celebrities are used to endorse a modern trade channel, the effectiveness and the impact has to be evaluated and analyzed to have a proper understanding and for effective future decision making for the companies. It is also sensible to have an in-depth analysis into the 'Vampire Effect' of the celebrity brand endorsement because the celebrity often overshadowing than the brand which could be a problematic area for the company. 


\section{References:}

[1] Agrawal, J., \& Kamakura, W. A. (1995). The Economic Worth Of Celebrity Endorsers: An Event Study Analysis. Journal Of Marketing, 59(3), 56-62. Doi:10.2307/1252119

[2] Belch, G. E., Belch, G. E., \& Belch, M. A. (2001). Advertising And Promotion: An Integrated Marketing Communications Perspective (5 Ed.). Irwin/Mcgraw-Hill, 2001.

[3] Boon, S. D., \& Lomore, C. D. (2006). Admirer-Celebrity Relationships Among Young Adults. Human Communication Research, 27, 432-465. Doi:10.1111/J.1468-2958.2001.Tb00788.X

[4] Buksa, I., \& Mitsis, A. (2011). Generation Y's Athlete Role Model Perceptions On PWOM Behavior. Young Consumers Insight And Ideas For Responsible Marketers, 12(4), 337-347. Doi:10.1108/17473611111185887

[5] Bush, A. J., Martin, C. A., \& Bush, V. D. (2004). Sports Celebrity Influence On The Behavioral Intentions Of Generation Y. Journal Of Advertising Research, 44(1), 108-118. Doi:10.1017/S0021849904040206

[6] Byrne, A., Whitehead, M., \& Breen, S. (2003). The Naked Truth Of Celebrity Endorsement. British Food Journal, 105(4). Doi:Https://Doi.Org/10.1108/00070700310477086

[7] Choi, C. J., \& Berger, C. (2010). Ethics Of Celebrities And Their Increasing Influence In 21st Century Society. Journal Of Business Ethics, 91, 313-318.

[8] Choudhury, D., \& Iyer, V. (2008). Celebrity Advertising: Does It Make Things Easy? Retrieved From Http://Www.Advancedge. Com/Archives/Jan05/

[9] Cooper, M. (1984). Can Celebrities Really Sell Products? Marketing And Media Decisions, 64-65.

[10] Daneshvary, R., \& Schwer, R. K. (2000). The Association Endorsement And Consumers' Intention To Purchase. Journal Of Consumer Marketing, 17(3), 203-213. Doi:10.1108/07363760010328987

[11] Dissanayake, R. (2018). Impact Of Perceived Effectiveness Of Celebrity Endorsement On Perceived Brand Relationship Behavior In The Services Sector In Sri Lanka.

[12] Dissanayake, R., \& Ismail, N. (2015). Relationship Between Celebrity Endorsement And Brand Attitude: With Reference To Financial Services Sector Brands In Sri Lanka. International Conference On Business And Information (ICBI), 6. Retrieved From Https://Www.Researchgate.Net/Publication/303767173_Relationship_Between_Celebrity_Endors 
ement_And_Brand_Attitude_With_Reference_To_Financial_Services_Sector_Brands_In_Sri_La nka

[13] Erdogan, Z. (1999). Celebrity Endorsement: A Literature Review. Journal Of Marketing Management, 15, 291-314. Doi:10.1362/026725799784870379

[14] Fitch Ratings Ltd. (2017). Spotlight: Sri Lankan Modern Grocery Retail. Retrieved From Https://Lmd.Lk/Wp-Content/Uploads/2017/11/Spotlight-Sri-Lankas-Modern-Grocery-RetailNov-2017.Pdf

[15] FT, D. (2013, October). Kumar Sangakkara Takes The Message Of 'Super Happy' To Keells Super Customers. Retrieved From Daily FT: Http://Www.Ft.Lk/Hr/Kumar-Sangakkara-Takes-TheMessage-Of-Super-Happy-To-Keells-Super-Customers/47-198096

[16] Hamza, M. (2019, October). Keells Supermarkets Journey On Retail Innovation. Retrieved From Echelon.Lk: Https://Echelon.Lk/Keells-Supermarkets-Journey-On-Retail-Innovation/

[17] Hennayake, H. (2017). Effectiveness Of Celebrity Endorsement: A Review On Related Concepts And Empirical Applications. International Journal Of Scientific \& Engineering Research, 7(7). Retrieved From File:///C:/Users/DOA\%20LAB/Downloads/Effectiveness-Of-CelebrityEndorsement-A-Review-On-Related-Concepts-And-Empirical-Applications.Pdf

[18] Hovland, C. I., Janis, I. L., \& \& Kelley, H. H. (1953). Communication And Persuasion; Psychological Studies Of Opinion Change. Yale University Press.

[19] Hovland, C., Janis, I., \& Kelley, H. (1954). Communication And Persuasion. Audio-Visual Communication Review, 2(2).

[20] Hung, K. (2014). Why Celebrity Sells: A Dual Entertainment Path Model Of Brand Endorsement. Journal Of Advertising, 43(2), 155-166.

[21] Ibok, N. I. (2013). Factors Determining The Effectiveness Of Celebrity Endorsed Advertisements: The Case Of Nigerian Telecommunication Industry. American Journal Of Business And Management, 2(3), 233-238. Doi:10.11634/216796061302394

[22] Kamins, M. (1990). An Investigation Into The "Match-Up" Hypothesis In Celebrity Advertising: When Beauty May Be Only Skin Deep. Journal Of Advertising, 19(1).

[23] Kamins, M. A., \& Gupta, K. (1994). Congruence Between Spokesperson And Product Type: A Matchup Hypothesis Perspective. Psychology \& Marketing, 11(6), 569-586. Doi:10.1002/Mar.4220110605 
[24] Khan, S., Nasir, N., Sabri, P. S., \& Nasir, S. (2016). Celebrity Endorsement And Consumer Buying Intention With The Mediating Role Of Brand Performance: An Empirical Consumer Perception Study In Fmcg Sector Of Pakistan. Sci.Int.(Lahore), 28(1), 617-624.

[25] Koththagoda, K., \& Weerasiri, S. (2017). Celebrity Endorsement And Purchase Intention Of Telecommunication Industry In Sri Lanka. International Journal Of Science And Research (IJSR), $6(6)$.

[26] Kulkarni, S., \& Gaulkar, S. (2005). Impact Of Celebrity Endorsement On Overall Brands. Retrieved From Www.Celebritiesnetwork.Com.: Http://Www.Celebritiesnetwork.Com.

[27] Kumara, W. (2016). The Role Of Fantasy On The Influence Of Effectiveness Of Celebrity Endorsements In Evaluating Endorsed-Brands. Sri Lanka Journal Of Marketing, 2(2), 1-16.

[28] Madhuhansi, T. (2017). Celebrity Endorsement On Consumer Purchase Intention For Milk Powder Market, Sri Lanka. 2nd Interdisciplinary Conference Of Management Researchers.

[29] Makgosa, R. (2010). The Influence Of Vicarious Role Models On Purchase Intentions Of Botswana Teenagers. Young Consumers Insight And Ideas For Responsible Marketers, 11(4), 307319. Doi:10.1108/17473611011093934

[30] Mawilmada, A. (2017). Sri Lanka's Evolving Retail Environment And The Need For Change. Retrieved From Daily Ft.

[31] Mccracken, G. (1989). Who Is The Celebrity Endorser? Cultural Foundations Of The Endorsement Process. Journal Of Consumer Research, 16(3). Doi:10.1086/209217

[32] Mcguire, W. (1985). Attitudes And Attitude Change (2 Ed.).

[33] Misra, S., \& Beatty, S. E. (1990). Celebrity Spokesperson And Brand Congruence. An Assessment Of Recall And Affect. Journal Of Business Research, 21(2), 159-173. Doi:10.1016/01482963(90)90050-N

[34] Mukherjee, D. (2009). Impact Of Celebrity Endorsements On Brand Image. SSRN Electronic Journal, 42(2). Doi:10.2139

[35] Perera, G. N., Dissanayake, D. M., \& Wanninayake, W. M. (2018). Influence Of Celebrity Worship Motives (CWM) On Customer Brand Relationship (CBR) Towards Services Brands. Archives Of Business Research, 6(8). Doi:10.14738/Abr.68.4963. 
[36] Priyankara, R., Weerasiri, S., Dissanayake, R., \& Jinadasa, M. (2018). Celebrity Endorsement And Consumer Buying Intention With Relation To The Television Advertisement For Perfumes. Journalism And Mass Communication, 5(2), 128-148.

[37] Redenbach, A. (2000). A Multiple Product Endorser Can Be A Credible Source. Cyber-Journal Of Sport Marketing, 3.

[38] Seno, D., \& Lukas, B. A. (2007). The Equity Effect Of Product Endorsement By Celebrities: A Conceptual Framework From A Co-Branding Perspective. European Journal Of Marketing, 41(1), 121-134. Doi:10.1108/03090560710718148

[39] Shiffman, L., \& Kanuk, L. (2006). Consumer Behavior (Vol. 9). Pearson Prentice Hall.

[40] Shimp, T. (2003). Advertising, Promotion And Supplemental Aspects Of Integrated Marketing Communications (6 Ed.). Thomson South Western.

[41] Shimp, T. (2010). Advertising Promotion And Other Aspects Of Integrated Marketing (Vol. 8).

[42] Spry, A., Pappu, R., \& Cornwell, T. B. (2008). Celebrity Endorsement, Brand Credibility And Brand Equity. European Journal Of Marketing, 45.

[43] Temperley, J., \& Tangen, D. (2006). The Pinocchio Factor In Consumer Attitudes Towards Celebrity Endorsement: Celebrity Endorsement, The Reebok Brand, And An Examination Of A Recent Campaign. Innovative Marketing, 2(3).

[44] Till, B. D., \& Shimp, T. A. (2013). Endorsers In Advertising: The Case Of Negative Celebrity Information. Journal Of Advertising, 27(1), 67-82. Doi:10.1080/00913367.1998.10673543

[45] Tripp, C., Jensen, T. D., \& Carlson, L. (1994). The Effect Of Multiple Product Endorsements By Celebrities On Consumers' Attitudes And Intentions. Journal Of Consume Research, 20.

[46] Udovita, P., \& Hilal, M. M. (2018). Factors Determining Celebrity Endorsement And Impact On Brand Loyalty: A Sri Lanka Based Study On Cosmetic Advertising. SEUSL Journal Of Marketing, $3(2)$.

[47] UK Essays. (2018, November). The Supermarket Industry In Sri Lanka. Retrieved From Ukessays: Https://Www.Ukessays.Com/Essays/Marketing/The-Supermarket-Industry-In-Sri-LankaMarketing-Essay.Php?Vref=1

[48] Wanninayake, W., \& Randiwela, P. (2007). The Impact Of Visual Merchandising On Consumer Store Choice Decisions In Sri Lankan Supermarkets. 7th Global Conference On Business \& Economics. Italy. 
[49] Yoo, B., \& Donthu, N. (2001). Developing And Validating A Multidimensional Consumer-Based Brand Equity Scale. Journal Of Business Research, 52(1), 1-14. Doi:10.1016/S01482963(99)00098-3 